\title{
Sociedade Portuguesa de Autores Atribui Prémio Mariano Gago ao Professor João Monte pelo seu Livro O Bairro da Tabela Periódica
}

No passado dia 25 de maio, por ocasião da celebração do Dia do Autor Português e do 96. aniversário da Sociedade Portuguesa de Autores (SPA), foi entregue a João Monte, Professor Jubilado da Faculdade de Ciências da Universidade do Porto, o prémio Mariano Gago. Este prémio foi criado em 2018 pela SPA e visa estimular a divulgação da investigação científica, premiando e dando notoriedade pública às obras de carácter científico.

A obra premiada, O Bairro da Tabela Periódica, foi publicada pela Editora da Universidade do Porto em 2019, contando com o patrocínio da Sociedade Portuguesa de Química, numa singela homenagem do autor às celebrações do Ano Internacional da Tabela Periódica decretado pela Assembleia Geral das Nações Unidas.

No âmbito das celebrações do AITP2019 a SPQ decidiu levar à cena esta obra tendo para o efeito contratado os serviços do encenador Mário Montenegro e da companhia Marionet de Coimbra. Durante o referido ano a companhia efetuou uma tournée pelas principais zonas metropolitanas do país, com exibições em Carnaxide (Teatro Rui de Carvalho), Coimbra (Teatro Gil Vicente) e Porto (Teatro Helena Sá da Costa). A tournée redundou num estrondoso sucesso tendo a atuação do elenco de atores dirigidos por Mário Montenegro sido vista por mais de 3200 espectadores presenciais.

A finalizar deixamos a opinião de três conceituados cientistas sobre a obra do Manuel João Monte, juntando-nos ao coro dos que aplaudem esta obra e que aguardam ansiosos pela encenação da sua nova obra, que visita um dos apartamentos de O Bairro da Tabela Periódica: O Arsenicum.

"Cheio de surpresas curiosas e revelações fascinantes, este texto denuncia também a evidência de que, até nos elementos, conseguimos discriminar o género feminino. E, de forma subtil, enquanto transmite noções fundamentais da química deixa-nos entretidos. Enjoy it as I did!"

\section{Alexandre Quintanilha}

"Manuel João Monte sonhou estes mesmos elementos, que hoje já são 118, arrumados nos seus quatro blocos para discutir as suas diferentes afinidades e antagonismos. É da diversidade que se faz a Química e também este mundo onde vivemos

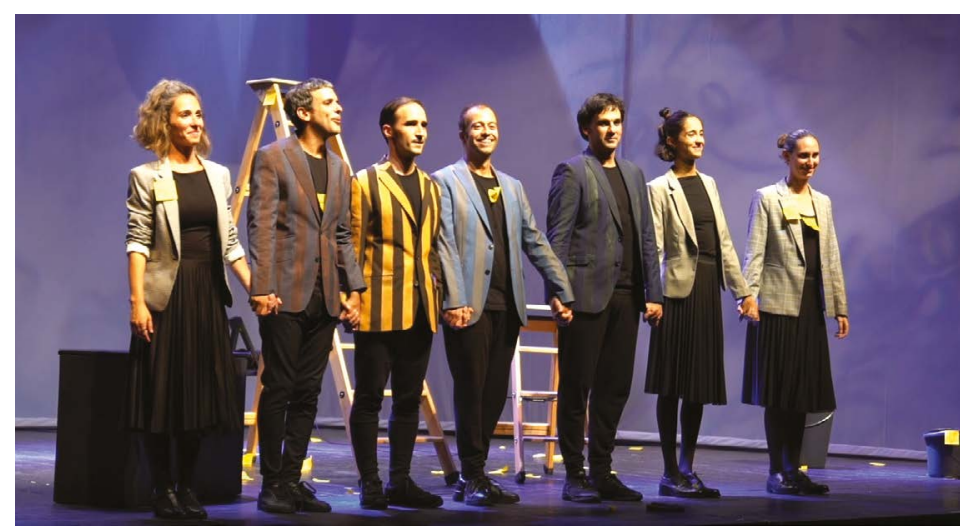

e de que somos feitos nós próprios. A Química dá força a um argumento que junta os dramas da vida humana com o grande drama da natureza." José Ferreira Gomes

"Há um bocado de tudo, desde referências ao Big Bang e à matéria escura, a uma interessante discussão sobre a dicotomia de identidade-efemeridade dos elementos radioativos e transuranianos ... Por tudo isto e muito mais, "O Bairro da Tabela Periódica" de Manuel João Monte é um texto de muito grande valor pedagógico e que merece uma leitura atenta." Orfeu Bertolami

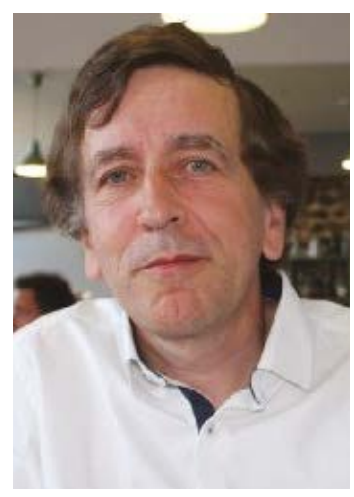

\section{Adelino Galvão}

Professor Auxiliar do Departamento de Engenharia Química, Instituto Superior Técnico, Universidade de Lisboa. Desenvolve o seu trabalho de investigação no Centro de Química Estrutural na área da Fotoquímica Computacional. É Secretário-Geral da SPQ desde 2017. adelino@tecnico.ulisboa.pt ORCID.org/0000-0002-4740-0613 